\title{
Effect of lead acetate toxicity on experimental male albino rat
}

\author{
Nabil M Ibrahim ${ }^{1}$, Esam A Eweis ${ }^{1}$, Hossam S El-Beltagi ${ }^{2 *}$, Yasmin E Abdel-Mobdy ${ }^{1}$ \\ ${ }^{l}$ Department of Economic Entomology and Pesticides, Faculty of Agriculture, Cairo University \\ ${ }^{2}$ Department of Biochemistry, Faculty of Agriculture, Cairo University, P. Box 12613, Gamma St,. Giza, Cairo, Egypt
}

\section{ARTICLE INFO}

Article history:

Received 25 May 2011

Received in revised form 7 June 2011

Accepted 28 June 2011

Available online 28 January 2012

\section{Keywords:}

Lead

Toxicity

ALT

AST

Cholinesterase

T3

T4

Lead acetate

Intoxication

Hemoglobin

\section{ABSTRACT}

Objective: To evaluate the effect of different doses of lead acetate $\left(1 / 20,1 / 40\right.$ and $1 / 60$ of $\left.L_{50}\right)$ on body weight gain, blood picture, plasma protein profile and the function of liver, kidney and thyroid gland. Methods: Male albino rats were divided into four groups, the first group represented the health control animals, while the second, third and fourth groups were ingested orally with sub lethal doses of lead acetate $(1 / 20,1 / 40$ and $1 / 60)$ of the oral $\mathrm{LD}_{50}$, respectively. One dose was ingested every two days during the experimental period (14 weeks) including the adaptation time. Blood was collected and used for all analysis. Results: The results showed that, the ingestion of $\mathrm{Pb}^{2+}$ induced significant stimulation in glutamic-pyruvic transaminase (ALT) and glutamic-oxalacetic transaminease (AST) activity. Also, total soluble protein and albumin contents of plasma were significantly decreased, while the content of globulin was changed by the $\mathrm{Pb}^{2+}$ treatments. The cholinesterase activity was inhibited, but the activities of alkaline and acid phosphates and lactate dehydrogenase were stimulated, while plasma glucose level was elevated as a result of lead acetate intoxication. In case of blood picture, $\mathrm{Pb}^{2+}$ ingestion reduced the contents of hemoglobin and RBCs count of intoxicated rat's blood and the plasma levels of T3, T4 and blood WBCs count were decreased. Conclusions: It can be concluded that lead acetate has harmful effect on experimental male albino rats. Therefore, the present work advises people to prevent exposure to the lead compound to avoid injurious hazard risk.

\section{Introduction}

Environmental pollution is the presence of a pollutant in environment such as air, water, soil and consequently in food which may be poisonous or toxic and will cause harm to living things in the polluted environment[1]. The excessive amount of pollutants such as heavy metals in animal feed and feed stuffs are often due to human actions, resulting from either agricultural or industrial production or accidental or deliberate misuse[2-5]. There are at least 18 elements that characterize one or more inorganic pesticides. Of these elements, eight (barium, cadmium, mercury, thallium, lead, bismuth, antimony and boron) have not been shown to be essential to the growth of animals[6]. In the instances, a series of elements, such as the heavy metal have been considered in the order of their atomic number. The definition of a heavy metal is one that has a specific gravity of more than $5 \mathrm{~g} / \mathrm{cm}^{3}$. By definition this would account for 60 metals several of which are biologically

*Corresponding author: Hossam S El-Beltagi, Associate Professor, Department of Biochemistry, Faculty of Agriculture, Cairo University, P. Box 12613, Gamma St, Giza, Cairo, Egypt.

Tel: 002-02-37742600, 0123532639

Fax: $002-02-35717355$

E-mail: lbltg@yahoo.com

Foundation Project: Supported by Management of Agriculture, Cario University. essential and many other lack sufficient information regarding toxicity including platinum, silver and gold. This arrangement of the elements helps to explain the chemistry and toxicology of their compound[7].

Many heavy metals, including $\mathrm{Pb}$, are known to induce over production of reactive oxygen species (ROS) and consequently enhance lipid peroxidation, decrease the saturated fatty acids and increase the unsaturated fatty acid contents of membranes[8]. Also, it has been shown to enhance the production of ROS in a variety of cells resulting oxidative stress[9]. ROS are the byproducts of many degenerative reactions in many tissues, which will affect the regular metabolism by damaging the cellular components[10]. Extensive study on oxidative stress has demonstrated that exposure of cells to adverse environmental conditions can induce the over production of ROS, such as superoxide radical $\left(\mathrm{O}_{2}^{-}\right), \mathrm{H}_{2} \mathrm{O}_{2}$ and hydroxyl radical $\left(\mathrm{OH}^{-}\right)$in plant cells[11]. In addition, ROS are highly reactive to membrane lipids, protein and DNA. They are believed to be the major contributing factors to stress injuries and to cause rapid cellular damage[12-17].

Traces of lead occur in many rocks in addition to those that are qualified as over lead, thus it can find its way into soil and water and hence into food, animals and human tissues even in remote places where there is no use of 
the metal or its compounds. In spite of its widespread distribution in tissues, there is no indication of no beneficial effect, but it causes many problems to the plant, food industry and animal health. Although various countries have established legislation regulating their concentration, they are still sometimes a danger for consumer health[18].

Lead is translocated through the food chain to man and animals, its toxicity depends on its chemical form administrated to the animal, the route of administration and the frequency and duration administered to animals[19]. Lead is one of the toxic metals, it is dangerous to most human body organ if exposure exceed to lerable levels. Lead can affect individuals of any age, but it has a disproportionate effect on children because their behavioral patterns place them at higher risk for exposure to lead. Their bodies absorb a larger percentage of the lead that they ingest and they exhibit lead toxicity at lower level for exposure than adults do[19]. Accumulation of lead produces damaging effects in the hematopoetical, hematic, renal and gastrointestinal system[20]. The toxicity of lead is closely related to age, sex, route of exposure level of intake, solubility, metal oxidation state, retention percentage, duration of exposure, frequency of intake, absorption rate, mechanisms and efficiency of excretion. Lead has been associated with various forms of cancer, nephrotoxicity, central nervous system effects and cardiovascular diseases in human[21]. The inhalation of lead could permanently lower intelligence quotient (IQ), damage emotional stability and cause hyperactivity, poor school performance and hearing loss. Foods of animals origin do not usually have excessive lead concentrations. Animal tissues with the highest concentration are liver, kidneys and bone and lead concentrations in milk are usually much lower than blood levels[22]. Animals (buffalo, cattle and others) had different levels of lead, some of them were more than the permissible limits such as meat muscles[23,24]. Also chicken meat contained lead like those of animals[25]. Excess lead is known to reduce the cognitive development and intellectual performance in children and to increase blood pressure and cardiovascular diseases incidence in adults[26].

Therefore, the aim of the present work is to evaluate the effect of different doses of lead acetate (1/20, 1/40 and 1/60 of $\mathrm{LD}_{50}$ ) on body weight gain, blood picture, plasma protein profile and the function of liver, kidney and thyroid gland.

\section{Materials and methods}

Lead acetate was obtained from Sigma Chemical Company, Egypt. A total of 24 (2-3 month old) male albino rats of body weight ranging from (100-150 g) (Rattus norvegicus Sprague Dawley strain) were obtained from the Animal House of Nutrition Institute, Cairo. These animals were housed in the Laboratory Animal Center of the Faculty of Agricultural, Cairo University, Giza, Egypt. The animals were divided into four groups (6 rats each) and kept under normal health laboratory conditions and adapted for two weeks. They were allowed free access to tap water and fed on the standard basal diet consisting of a mixture of $20 \%$ casein, $10 \%$ cotton seed oil, $5 \%$ cellulose, $4 \%$ salt mixture, $1 \%$ vitamin mixture and $60 \%$ starch[27]. The first group represented the health control animals, while the second, third and fourth groups were ingested orally with sub lethal doses of lead acetate which were $1 / 20,1 / 40$ and $1 / 60$ of the oral $\mathrm{LD}_{50}$, respectively. The lead acetate doses were dissolved in $0.5 \mathrm{~mL}$ water. One dose was ingested every two days during the experimental period (14 weeks) including the adaptation time. Food and water were supplied ad libitum for all groups during the period of experiment.

Each rat was weighed every week and its daily food intake was determined. Feed efficiency was calculated as the following equation (body weigh gain / food intake). At the end of the experimental period (12 weeks), animals were killed by decapitation. Blood was collected, some of which was centrifuged at $3000 \mathrm{rpm}$ to obtain the plasma which was kept frozen at $-20{ }^{\circ} \mathrm{C}$ until used for analysis. The other blood was used to determine the blood picture in which total hemoglobin was determined[28]. Red blood cells (RBCs) and white blood cells (WBCs) were counted after decapitation immediately as pointed out[29]. Plasma total bilirubin was determined as demonstrated[30]. Determination of total soluble protein and albumin in plasma was carried out[31,32], respectively, plasma globulin was calculated by the difference between total protein and albumin. Plasma glutamic-oxalacetic transaminease (AST) and glutamic-pyruvic transaminase (ALT) activities were determined[33]. Plasma total thyroxine (T4) was determined by radioimmunoassay procedure[34] and plasma triiodothyronine was measured by double antibody technique. Cholinesterase, acid phosphatase, alkaline phosphatase and lactate dehydrogenases activities were determined[35-38]. Plasma glucose values were determined according to the method of Trinder[39].

All data pooled through this study were preceded by General Linear Model procedures (GLM) of the statistical analysis system described in SAS User's Guide[40]. The significance of the differences among treatment groups was tested using Waller-Duncan $\mathrm{k}$-ratio[41]. All statements of significance were based on probability of $P<0.05$.

\section{Results}

The results in Table 1 showed that, means that gain in body weight and feed efficiency were lowered relative to control which were reduced to $56 \%$ and $50 \%, 58 \%$ and $56 \%$, $60 \%$ and $67 \%$, respectively under the treatment by ingestion of $1 / 20,1 / 40$ and $1 / 60$ of the $\mathrm{LD}_{50}$ of lead acetate relative to the healthy normal control. Also, the present results in Table 2 showed that weight of four examined organs (liver, kidneys, heart and spleen) was affected by lead acetate ingestion. There was a significant increase in the organs weight after the experimental period, either in organs weight or the ratio $\%$ relative to final body weight.

In the case of liver function, the parameters including plasma AST and ALT activities and plasma bilirubin levels are used to check liver function in the intoxicated animals relative to the health normal rats (Table 3). These results showed that $\mathrm{Pb}^{2+}$ ingestion highly and significantly stimulated the activity of AST and ALT. Data of plasma bilirubin showed highly significant elevation in bilirubin value in $\mathrm{Pb}^{2+}$ intoxicated rats relative to the control after the experimental period. The three doses of $\mathrm{Pb}^{2+}$ ingestion exhibited nearly the same levels of plasma bilirubin. Protein profile of plasma was changed under the ingestion of lead acetate. The results reported significant reduction in total soluble protein and albumin, while plasma globulin value was insignificantly changed. The effects of lead acetate on enzymes activities were shown in Table 4. Cholinesterase 
showed marked decrease in its activity as a result of lead acetate treatments. The inhibition was gradually paralleled with the $\mathrm{Pb}^{2+}$ ingested doses increased, until it reached the maximum value at $1 / 20 \mathrm{LD}_{50}$ of lead acetate treatment $(80.21$ $\mu \mathrm{g} / \mathrm{dL})$ in comparison with control $(110.10 \mu \mathrm{g} / \mathrm{dL})$. While the results of acid and alkaline phosphatase showed that, activities of both enzymes in intoxicated rats with lead were stimulated relative to non-toxicated control group. Also, lead acetate treatments $\left(1 / 20 \mathrm{LD}_{50}, 1 / 40 \mathrm{LD}_{50}, 1 / 60 \mathrm{LD}_{50}\right)$ showed gradually inhibition in lactate dehydrogenase $(\mathrm{LDH})$

Table 1

Lead acetate toxicity on the body weight gain, food intake and feed efficiency of the experimental animals (mean \pm SD).

\begin{tabular}{|c|c|c|c|c|c|c|c|c|}
\hline \multirow{2}{*}{$\begin{array}{l}\text { Lead acetate } \\
\text { treatments }\end{array}$} & \multirow{2}{*}{$\begin{array}{l}\text { Initial body } \\
\text { weight }(\mathrm{g})\end{array}$} & \multirow{2}{*}{$\begin{array}{l}\text { Final body } \\
\text { weight }(\mathrm{g})\end{array}$} & \multirow{2}{*}{$\begin{array}{l}\text { Body weight } \\
\text { gain }(\mathrm{g})\end{array}$} & \multirow{2}{*}{$\begin{array}{l}\text { The gain to normal } \\
\text { control }(\%)\end{array}$} & \multirow{2}{*}{ Food intake- } & \multicolumn{2}{|c|}{ Feed efficiency (FE) } & \multirow{2}{*}{$\begin{array}{l}\text { Feed efficiency to } \\
\text { normal control }(\%)\end{array}$} \\
\hline & & & & & & Value & $100(\mathrm{FE})$ & \\
\hline Normal control & $197 \pm 11$ & $367 \pm 10$ & $170 \pm 9$ & 100 & $944 \pm 50$ & $0.18 \pm 0.02$ & 18 & 100 \\
\hline Oral $1 / 20 \mathrm{LD}_{50}$ & $165 \pm 9$ & $269 \pm 11$ & $95 \pm 5 *$ & 56 & $1056 \pm 39$ & $0.09 \pm 0.01 *$ & 9 & 50 \\
\hline Oral $1 / 40 \mathrm{LD}_{50}$ & $175 \pm 9$ & $273 \pm 12$ & $98 \pm 6^{*}$ & 58 & $981 \pm 50$ & $0.10 \pm 0.01 *$ & 10 & 56 \\
\hline Oral $1 / 60 \mathrm{LD}_{50}$ & $197 \pm 15$ & $299 \pm 13$ & $102 \pm 6^{*}$ & 60 & $850 \pm 44$ & $0.12 \pm 0.01 *$ & 12 & 67 \\
\hline LSD 5\% & & & 36 & & & 0.05 & & \\
\hline
\end{tabular}

$\%$ : relative to control; *: $P<0.05$ comparing with control.

Table 2

Lead acetate toxicity on organs weight ratio of the experimental animals (mean \pm SD).

\begin{tabular}{|c|c|c|c|c|c|c|c|c|c|c|c|c|c|}
\hline \multirow{2}{*}{$\begin{array}{l}\text { Lead acetate } \\
\text { treatments }\end{array}$} & \multirow{2}{*}{$\begin{array}{c}\text { Body } \\
\text { weight }(g)\end{array}$} & \multicolumn{3}{|c|}{ Liver } & \multicolumn{3}{|c|}{ Kidney } & \multicolumn{3}{|c|}{ Heart } & \multicolumn{3}{|c|}{ Spleen } \\
\hline & & Weight (g) & Ratio $(\%)$ & $\%$ & Weight (g) & Ratio $(\%)$ & $\%$ & Weight (g) & Ratio $(\%)$ & $\%$ & Weight (g) & Ratio $(\%)$ & $\%$ \\
\hline Normal control & $367 \pm 10$ & $14.98 \pm 1.00$ & $4.08 \pm 0.41$ & 100 & $2.50 \pm 0.13$ & $0.68 \pm 0.10$ & 100 & $1.40 \pm 0.08$ & $0.38 \pm 0.00$ & 100 & $2.05 \pm 013$ & $0.56 \pm 0.01$ & 100 \\
\hline Oral $1 / 20 \mathrm{LD}_{50}$ & $260 \pm 11$ & $16.12 \pm 1.00$ & $6.20 \pm 0.32 *$ & 152 & $3.90 \pm 0.14$ & $1.50 \pm 0.10^{*}$ & 220 & $1.87 \pm 0.10$ & $0.72 \pm 0.00 *$ & 189 & $2.31 \pm 0.09$ & $0.89 \pm 0.00 *$ & 159 \\
\hline Oral $1 / 40 \mathrm{LD}_{50}$ & $273 \pm 12$ & $15.04 \pm 0.92$ & $5.51 \pm 0.92^{*}$ & 135 & $3.55 \pm 0.14$ & $1.30 \pm 0.01 *$ & 191 & $1.80 \pm 0.11$ & $0.66 \pm 0.00 *$ & 174 & $2.07 \pm 0.11$ & $0.76 \pm 0.00^{*}$ & 136 \\
\hline Oral $1 / 60 \mathrm{LD}_{50}$ & $299 \pm 13$ & $16.12 \pm 0.92$ & $5.39 \pm 0.29^{*}$ & 132 & $2.99 \pm 0.08$ & $1.00 \pm 0.00 *$ & 147 & $1.52 \pm 0.06$ & $0.51 \pm 0.00 *$ & 134 & $2.12 \pm 0.07$ & $0.71 \pm 0.00^{*}$ & 127 \\
\hline LSD 5\% & & & 0.51 & & & 0.14 & & & 0.04 & & & 0.07 & \\
\hline
\end{tabular}

$\%$ : relative to control; *: $P<0.05$ comparing with control.

Table 3

Lead acetate toxicity on plasma total soluble protein profile and liver function of the experimental animals (mean \pm SD).

\begin{tabular}{|c|c|c|c|c|c|c|c|c|c|c|c|c|}
\hline \multirow[t]{2}{*}{ Lead acetate treatments } & \multicolumn{2}{|c|}{$\begin{array}{c}\text { Total soluble } \\
\text { protein }\end{array}$} & \multicolumn{2}{|c|}{ Albumin } & \multicolumn{2}{|c|}{ Globulin } & \multicolumn{2}{|c|}{ Total bilirubin } & \multicolumn{2}{|c|}{ AST activity } & \multicolumn{2}{|c|}{ ALT activity } \\
\hline & $\mathrm{g} / \mathrm{dL}$ & $\%$ & $\mathrm{~g} / \mathrm{dL}$ & $\%$ & $\mathrm{~g} / \mathrm{dL}$ & $\%$ & $\mathrm{mg} / \mathrm{dL}$ & $\%$ & $\mathrm{U} / \mathrm{L}$ & $\%$ & $\mathrm{U} / \mathrm{L}$ & $\%$ \\
\hline Normal control & $7.00 \pm 0.41$ & 100 & $4.60 \pm 0.26$ & 100 & $2.40 \pm 0.12$ & 100 & $0.34 \pm 0.12$ & 100 & $60.00 \pm 4.76$ & 100 & $32.00 \pm 2.01$ & 100 \\
\hline Oral $1 / 20 \mathrm{LD}_{50}$ & $4.50 \pm 0.22 *$ & 64 & $2.32 \pm 0.18^{*}$ & 50 & $2.18 \pm 0.14 *$ & 91 & $4.00 \pm 0.33 *$ & 1176 & $120.00 \pm 7.21 *$ & 200 & $65.71 \pm 4.10^{*}$ & 205 \\
\hline Oral $1 / 40 \mathrm{LD}_{50}$ & $4.72 \pm 0.29^{*}$ & 67 & $2.59 \pm 0.17 *$ & 56 & $2.13 \pm 0.16^{*}$ & 89 & $3.01 \pm 0.22 *$ & 885 & $115.00 \pm 6.07 *$ & 192 & $60.00 \pm 3.51^{*}$ & 188 \\
\hline Oral $1 / 60 \mathrm{LD}_{50}$ & $4.59 \pm 0.30^{*}$ & 66 & $2.52 \pm 0.16^{*}$ & 55 & $2.07 \pm 0.19^{*}$ & 86 & $4.00 \pm 0.18 *$ & 1176 & $109.00 \pm 10.21^{*}$ & 182 & $53.78 \pm 3.50^{*}$ & 168 \\
\hline LSD 5\% & 1.24 & & 1.41 & & 0.34 & & 0.73 & & 1.89 & & 4.44 & \\
\hline
\end{tabular}

$\%$ : relative to control; *: $P<0.05$ comparing with control.

Table 4

Lead acetate toxicity on blood glucose, activities of cholinesterase, acid and alkaline phosphatase and lactic dehydrogenase in plasma of the experimental animals (mean $\pm \mathrm{SD}$ ).

\begin{tabular}{|c|c|c|c|c|c|c|c|c|c|c|}
\hline \multirow{2}{*}{ Lead acetate treatments } & \multicolumn{2}{|c|}{ Cholinesterase } & \multicolumn{2}{|c|}{ Alkaline phosphatase } & \multicolumn{2}{|c|}{ Acid phosphatase } & \multicolumn{2}{|c|}{ Lactate dehydrogenase } & \multicolumn{2}{|c|}{ Blood glucose value } \\
\hline & $\mu \mathrm{g} / \mathrm{dL}$ & $\%$ & IU/L & $\%$ & IU/L & $\%$ & $\mathrm{U} / \mathrm{L}$ & $\%$ & $\mathrm{mg} / \mathrm{dL}$ & $\%$ \\
\hline Normal control & $110.10 \pm 6.66$ & 100 & $120.01 \pm 7.01$ & 100 & $18.01 \pm 10.00$ & 100 & $210.00 \pm 12.00$ & 100 & $93.00 \pm 5.21$ & 100 \\
\hline Oral $1 / 20 \mathrm{LD}_{50}$ & $80.21 \pm 4.72 *$ & 73 & $241.00 \pm 13.21 *$ & 201 & $53.21 \pm 3.01 *$ & 295 & $377.00 \pm 18.11 *$ & 180 & $159.00 \pm 8.99^{*}$ & 171 \\
\hline Oral $1 / 40 \mathrm{LD}_{50}$ & $86.61 \pm 5.00^{*}$ & 79 & $201.21 \pm 12.11^{*}$ & 168 & $45.55 \pm 2.79 *$ & 253 & $359.70 \pm 17.97 *$ & 171 & $140.90 \pm 8.10^{*}$ & 152 \\
\hline Oral $1 / 60 \mathrm{LD}_{50}$ & $87.77 \pm 5.10 *$ & 80 & $213.72 \pm 12.01 *$ & 178 & $41.21 \pm 1.89^{*}$ & 229 & $333.10 \pm 16.78 *$ & 159 & $150.00 \pm 8.31^{*}$ & 161 \\
\hline LSD 5\% & 11.96 & & 25.16 & & 5.27 & & 20.21 & & 31.21 & \\
\hline
\end{tabular}

$\%$ : relative to control; *: $P<0.05$ comparing with control.

Table 5

Lead acetate toxicity on the blood picture, and thyroid hormones of male albino rats (mean \pm SD).

\begin{tabular}{|c|c|c|c|c|c|c|c|c|c|c|}
\hline \multirow{2}{*}{ Lead acetate treatments } & \multicolumn{2}{|c|}{ Total hemoglobin } & \multicolumn{2}{|c|}{ RBCs count } & \multicolumn{2}{|c|}{ WBCs count } & \multicolumn{2}{|l|}{$\mathrm{T} 4$} & \multicolumn{2}{|l|}{ T3 } \\
\hline & $\mathrm{g} / \mathrm{dL}$ & $\%$ & Value $\times 10^{6}$ & $\%$ & Value $\times 10^{3}$ & $\%$ & $\mu \mathrm{g} / \mathrm{dL}$ & $\%$ & $\mu \mathrm{g} / \mathrm{dL}$ & $\%$ \\
\hline Normal control & $15.00 \pm 1.01$ & 100 & $6.18 \pm 0.40$ & 100 & $5.99 \pm 0.30$ & 100 & $4.00 \pm 0.27$ & 100 & $93.00 \pm 6.16$ & 100 \\
\hline Oral $1 / 20 \mathrm{LD}_{50}$ & $10.88 \pm 0.72 *$ & 73 & $4.01 \pm 0.25^{*}$ & 65 & $5.79 \pm 0.35 *$ & 97 & $4.01 \pm 0.28 *$ & 100 & $90.00 \pm 5.37 *$ & 97 \\
\hline Oral $1 / 40 \mathrm{LD}_{50}$ & $12.17 \pm 0.67 *$ & 81 & $5.02 \pm 0.30^{*}$ & 81 & $6.00 \pm 0.41 *$ & 100 & $3.78 \pm 0.19 *$ & 95 & $91.00 \pm 4.99 *$ & 98 \\
\hline Oral $1 / 60 \mathrm{LD}_{50}$ & $12.72 \pm 0.71 *$ & 85 & $5.25 \pm 0.29 *$ & 85 & $6.12 \pm 0.34 *$ & 102 & $3.82 \pm 0.28 *$ & 96 & $91.00 \pm 5.55^{*}$ & 98 \\
\hline LSD 5\% & 2.02 & & 0.88 & & 0.15 & & 0.26 & & 4.10 & \\
\hline
\end{tabular}

$\%$ : relative to control; *: $P<0.05$ comparing with control. 
activity (377.00, 359.70 and 333.10). As shown in Table 4 blood glucose levels significantly increased under the lead acetate intoxication relative to control and reached its maximum $(159.00 \mathrm{mg} / \mathrm{dL})$ at $1 / 20 \mathrm{LD}_{50}$.

The results in Table 5 showed the effect of lead acetate toxicity on blood picture and thyroid hormones. Total hemoglobin $(\mathrm{Hb})$ levels were reduced by $\mathrm{Pb}^{2+}$ ingestion, this trend was observed also for RBCs count, but WBCs count was insignificantly changed relative to control. Also, the effect of $\mathrm{Pb}^{2+}$ toxicity on thyroid function was shown in Table 5. The levels of plasma T4 and T3 were reduced under the effects of lead acetate ingestion and the effects were paralleled relative with the dose of toxicant ingestion.

\section{Discussion}

The effect of lead acetate on body weight gain, food intake and feed efficiency was progressively increased during the experimental period of all different four groups. The final body weight of intoxicated rats with lead was significantly lower than that of the health normal group. These results clearly indicated that lead caused a significant decrease in the gain of body weight. This harmful effect of lead on the body weight gain was elevated paralleled with the increase of lead acetate doses. The severe effect was found in the rats ingested with $1 / 20 \mathrm{LD}_{50}$ lead acetate. The amount of food intake of the four groups was unchanged significantly. This means that the values of food intake were not paralleled to the rate of growth and feed efficiency. Also, feed efficiency was decreased under the effect of lead acetate relative to the health control which was concurred with the gain in body weight but not with food intake. The harmful effect of lead acetate ingestion in the present results was insignificantly increased with the increasing of its dose. The obtained results are in agreement with the findings in previous study. They found that lead caused decreases in growth rate in rats when fed lead[42]. These results in body weight gain which may be caused by the toxic ions could be associated with several factors, one of which is imbalance metabolism produced by impairing zinc status in zinc-dependent enzymes which are necessary for many metabolic processes. In addition, lead caused lower effects on liver and spleen than those on kidney and heart. These observations of $\mathrm{Pb}^{2+}$ ingestion are significantly increased paralleled with the increasing dose. The detected elevation in the organs weight or ratio was thought to be due to the necrosis and apoptosis which could be attributed to the accumulation of the lipids in the four organs. $\mathrm{Pb}^{2+}$ treatments produced a significant accumulation of lipids in kidney cells of rats[43]. Also, they reported that there was an increase in the dry weight of the kidney relative to body weight which may be due to a nutritional disturbance caused by pair feedings. A thorough review of tumorigenicity of lead salts in general, revealed that lead acetate is carcinogenic in rats or mice and the kidney is the most important and perhaps the target organ[44]. The dosages necessary to cause the conditions in animals far exceeded the maximal tolerated dosages in human.

The stimulation in ALT and AST levels was gradually paralleled with the increasing $\mathrm{Pb}^{2+}$ ingested doses, until it reached the highest value at $1 / 20 \mathrm{LD}_{50}$ of lead acetate treatment. That means the stimulations were found to be dose dependent. The effect of $\mathrm{Pb}^{2+}$ on AST activity was significantly similar to that of ALT. The lead acetate intoxication produced 10 fold of plasma bilirubin compared with the normal control (non-toxicated rats). The present results of the liver function parameters (ALT, AST and bilirubin) showed the damage in liver cell of $\mathrm{Pb}^{2+}$ intoxicated animals. These observations are in agreement with previous study which reported that lead has hepatotoxic effect[45]. The present results showed that effect of lead acetate on the transaminases activity is dose independent. The high plasma ALT and AST activities are accompanied by high liver microsomal membrane fluidity, free radical generation and alteration in the liver tissue histogram. The elevation of plasma bilirubin value under the ingestion of lead acetate may be due to the induction of heme oxygenase. The catabolism of heme from all heme proteins is carried out in the microsomal fraction of cells by a complex enzyme system and heme oxygenase is an enzyme which can convert heme to bilirubin[42,46]. They reported that bilirubin formed in different tissues is transported to liver as a complex with serum bilirubin. Bilirubin is conjugated with glucuronide in the smooth endoplasmic reticulum of liver, but under the effects of lead toxicity, the conjugation of bilirubin with glucouronoid will become inactive. This may be due to the peroxidation of membrane lipids of smooth endoplasmic reticulum. Bilirubin has a protective role against oxidative damage of cell membrane induced by metals[47]. The variation in total protein of plasma was correlated with the changes in albumin value. The reduction in plasma total soluble protein and albumin levels may be due to inhibition of protein biosynthesis through the specific enzymes in cell processes and low significant excretion of hormones (such as T3 and T4) in the present study which can regulate protein biosynthesis[46]. Also, lead treatment caused hepatic deficiency in copper and zinc which act as cofactor to antioxidant enzymes. The results of plasma protein profile found decreases in plasma albumin and the total soluble protein, but globulin was insignificantly though exposure to lead toxicity. This means that the alterations in total soluble protein values were correlated with the changed albumin levels. These may be due to inhibition of albumin biosynthesis through specific enzymes in cell processes and low significant excretion of hormones in the present study which can regulate protein biosynthesis. Heavy metals including lead can precipitate soluble protein and albumin in plasma is used as carrier for poison lead. About $9 \%$ of inorganic lead is transported mainly in the plasma[48].

Inhibition in plasma cholinesterase activity by lead acetate is usually used as an indicator exposure to pesticides[49]. The stimulations of acid and alkaline phosphatases were increased with the increasing lead acetate dose. Acid and alkaline phosphatase can be considered as markers of the possible neuro-toxicity of lead. Intoxication with lead was associated with alterations which caused renal toxicity and damage[50]. The effect of lead on renal function could be attributed to alterations in the antioxidant defensive system, resulting in kidney injury. LDH activity of intoxicated rats with lead acetate was stimulated compared with normal control. The effect was increased with the increasing $\mathrm{Pb}^{2+}$ dose. Lead acetate ingestion induced alteration in redox status as indicated by a decrease in glutathione levels, an increase in lipid peroxidation end-product-4hydroxynonenal levels which may be produced by damage 
in RBCs membrane and increased LDH in plasma[42]. The elevations in blood glucose levels may be due to the increases in the rate of glucose transport from the tissues to blood, glycogenolysis and gluconeogenesis or decreased rate removal of glucose from the blood to tissues. Present results which found a disorder in thyroid function (T4 and T3) in lead intoxicated rats are confirmed by the elevation of blood glucose levels and lead induced heapatoxicity by activation. Therefore, its selectivity causes toxicity in liver cells marinating semi-normalmetabolic function[51]. Although many enzymes are inhibited by $\mathrm{Pb}^{2+}$, no specific inhibition has been identified as the biochemical lesion. Antioxidant enzymes were affected by higher doses of $\mathrm{Pb}^{2+}[18,52]$. Heavy metals induced hepototoxicity through the depletion of glutathione and protein, resulting in enhanced production of reactive oxygen species such as peroxide ion, hydroxyl radical and $\mathrm{H}_{2} \mathrm{O}_{2}$. These reactive oxygen species increased lipids peroxidation and cell membrane damage. These alterations caused the leakage of liver enzymes into the blood. Delta-aminolevulinic acid was accumulated in liver by acute lead intoxication which caused a marked elevation in lipid peroxidation, reduced glutathione levels and inhibited the activity of many enzymes including antioxidative ones[53].

The reduction of $\mathrm{Hb}$ confirmed the decreases in RBCs which may be attributed to the toxicity of lead acetate. It is in agreement with the elevation of plasma bilirubin level by $\mathrm{Pb}^{2+}$ ingestion which could be due to the induction of heme oxygenase. The blood pressure was significantly increased compared with the control group. It is possible that $\mathrm{Pb}^{2+}$ can cause anemia and growth retardation. It is thought that the action of lead is particularly marked in the blood vessel and some effects are secondary to this injury[54]. In addition, lead acetate ingestion caused insignificantly reduction of levels of plasma T4 and T3. These are in agreement with previous study, they found that $\mathrm{Pb}^{2+}$ decreased the thyroxin (T4) and the 3,5-triiodothyronine (T3) levels with the concomitant rise in thyroid stimulator hormone (TSH) levels. This indicates that animals exposed to $\mathrm{Pb}^{2+}$ may be at a risk of thyroid damage[51]. It is established that $\mathrm{Pb}^{2+}$ induced hepatoxicity may be due to its selectivity in causing toxicity in the semi-normal metabolic function of the liver cells[55]. Lead treatment provoked increased lipid peroxidation, catalase activity, glutathione level but reduced superoxide dismutase activity as compared with normal rats. These results suggest the involvement of free radicals in the pathogenesis of $\mathrm{Pb}^{2+}$ poisoning[56,57]. Lead is a protoplasmic poison lead which can cause damages in many organic bodies. There is little doubt that the nervous system and kidney especially the tubules are affected directly[43]. Finally one of our interests in this investigation was to clearly show that acute intoxication with $\mathrm{Pb}^{2+}$ caused disturbance in the body metabolism as well as oxidative antioxidative balance in the different tissues and plasma. These results suggest that the harmful effect in the metabolism was produced by the $\mathrm{Pb}^{2+}$ toxicant which was increased by increasing the heavy metals $\left(\mathrm{Pb}^{2+}\right)$ dose. The present results advise people to prevent any exposure to $\mathrm{Pb}^{2+}$ compounds to avoid injurious hazard risk.

\section{Conflict of interest statement}

We declare that we have no conflict of interest.

\section{Acknowledgments}

Authors would like to thank the Management of the Faculty of Agriculture and, Cairo University for ongoing cooperation to support research and that provided funds and facilities necessary to achieve the desired goals of research.

\section{References}

[1] Duruibe JO, Ogwuegbu MOC, Egwurugwu JN. Heavy metal pollution and human biotoxic effects. Int J Phys Sci 2007; 2(5): 112-118.

[2] Aboul-Enein AM, Abou Elella FN, Abdullah ES. Monitoring of some organochlorines and organophosphorus residues in imported and locally raised chicken and bovine muscles in Egypt. J Appl Sci Res 2010; 6(6): 600-608.

[3] Mohamed AA, El-Beltagi HS, Rashed MM. Cadmium stress induced change in some hydrolytic enzymes, free radical formation and ultrastructural disorders in radish plant. Electron $J$ Environ Agric Food Chem 2009; 8(10): 967-983.

[4] El-Beltagi HS, Mohamed AA, Rashed MM. Response of antioxidative enzymes to cadmium stress in leaves and roots of radish (Raphanus sativus L.). Not Sci Biol 2010; 2(4): 76-82.

[5] Afify AMR, El-Beltagi HS. Effect of the insecticide cyanophos on liver function in adult male rats. Fresen Environ Bull 2011; 20(4a): 1084-1088.

[6] Hayes WJ, Laws ER. Handbook of pesticide toxicology. San Diego, New York and Tokyo: Academic Press, Inc. Harcourt Brace Jevanovich Publisher; 1991.

[7] Omaya ST. Introduction to food toxicology. In: Watson D. (ed.) Pesticides, veterinary and other chemical residues in food. Cambridge: Woodhead Publishing Ltd; 2004, p. 1-26.

[8] Malecka A, Jarmuszkiewicz W, Tomaszewska B. Antioxidative defense to lead stress in sub cellular compartments of pea root cells. Acta Biochim Pol 2001; 48: 687-698.

[9] Xienia U, Foote GC, Van S, Devreotes PN, Alexander S, Alexander H. Differential developmental expression and cell type specificity of Dictyostelium catalases and their response to oxidative stress and UV light. Biochim Biophys Acta 2000; 1492: 295-310.

[10] Foyer CH, Noctor G. Oxygen processing in photosynthesis: regulation and signaling. New Phytol 2002; 146: 359-388.

[11] Wise RR, Naylor AW. Chilling-enhanced peroxidation: the peroxidative destruction of lipids during chilling injury to photosynthesis and ultrastucture. Plant Physiol 1987; 83: 227-272.

[12] El-Beltagi HES, Salama ZA, El-Hariri DM. Some biochemical markers for evaluation of flax cultivars under salt stress conditions. J Nat Fiber 2008; 5(4): 316-330.

[13] Salama ZA, El-Beltagi HS, El-Hariri DM. Effect of Fe deficiency on antioxidant system in leaves of three flax cultivars. Not Bot Hort Agrobot Cluj 2009; 37(1): 122-128.

[14] Shehab GMG, Ahmed OK, El-Beltagi HS. Nitric oxide treatment alleviates drought stress in rice plants (Oryza sativa). Not Bot Hort Agrobot Cluj 2010; 38(1): 139-148.

[15] Aly AA, El-Beltagi HES. Influence of ionizing irradiation on the antioxidant enzymes of Vicia faba L. Grasa Y Aceite 2010; 61(3): 288-294.

[16] Afify AMR, El-Beltagi HS, Fayed SA, Shalaby EA. Acaricidal activity of successive extracts from Syzygium cumini L. Skeels (Pomposia) against Tetranychus urticae Koch. Asian Pac J Trop Biomed 2011; 1(5): 359-364. 
[17] El-Beltagi HS, Ahmed OK, El-Desouky W. Effect of low doses $\gamma$-irradiation on oxidative stress and secondary metabolites production of Rosemary (Rosmarinus officinalis L.) callus culture. Radiat Phys Chem 2011; 80(9): 965-973.

[18] El-Beltagi HS, Mohamed AA. Changes in non protein thiols, some antioxidant enzymes activity and ultrastructural alteration in radish plant (Raphanus sativus L.) grown under lead toxicity. Not Bot Hort Agrobot Cluj 2010; 38(3): 76-85.

[19] Baht RV, Moy GG. Monitoring and assessment of dietary exposure to chemical contaminants. WHO: Geneva; 1997, p. 132-149.

[20] Correia PRM, Oliveira E, Oliveira PV. Simultaneous determination of $\mathrm{Cd}$ and $\mathrm{Pb}$ in foodstuffs by electro-thermal atomic absorption spectrometry. Anal Chim Acta 2000; 405(1-2): 205-211.

[21] Pitot CH, Dragan PY. Chemical carcinogenesis. Casarett and Doull's toxicology. 5th ed. New York: McGraw Hill; 1996, p. 201-260.

[22] Donia AMA. Lead concentrations in different animals muscles and consumable organs at specific localities in Cairo. Glob Vet 2008; 2(5): 280-284.

[23] Demirezen D, Kadiriye U. Comparative study of trace elements in certain fish, meat and meat production. Meat Sci 2006; 74: $255-260$.

[24] Korenekova B, Skalicka M, Nai P. Concentration of some heavy metals in cattle reared in the vicinity of a metallurgic industry. Vet Arch 2002; 72(5): 259-267.

[25] Iwegbue GMA, Nwajei GE, Iyoha EH. Heavy metal residues of chicken, meat and gizzard and turkey meat consumed in southern Nigeria. Bulg J Vet Med 2008; 11(4): 275-280.

[26] Commission of the European Communities. Commission regulation (EC) No. 221/2002 of 6 February 2002 amending regulation (EC) NO. 466/2002 setting maximum levels for certain contaminants in foodstuffs. Brussels: Official Journal of the European Commucities; 2002.

[27] Lane-Part W, Pearson AE. Dietary requirements. Laboratory animal principles and practice. London and New York: Academic Press; 1971, p. 142.

[28] Decra JA, Lewis SM. Measurement of hemoglobin (cyanomethemoglobin method). Practical hematology. 5th ed. Edinburg, London and New York: Chuchill Livingstone; 1975, p. 32.

[29] Frankel S, Reitman, S. Clinical laboratory methods. St Louis: CV Mosby Company; 1963, p. 1102.

[30] Jendrassik L, Graf P. Bilirubin, determination of bilirubin in blood serum. In: Johne D, Bauer MD, Toro G, Ackermann PG. (eds.) Brays clinical laboratory methods. Washington DC: St. Louis; 1953, p. 357.

[31] Bradford MM. A rapid and sensitive method for the quantitation of microgram quantities of protein utilizing the principle of proteindye binding. Anal Biochem 1976; 72: 248-254.

[32] Doumas BT, Waston WA, Biggs AG. Biuret method for quantitative estimation of total protein in serum or plasma. Clin Chim Acta 1971; 31: 87-91.

[33] Ritman S, Frankel S. A colorimetric method for the determination of serum GOT and GPT. Am J Clin Pathol 1957; 28: 56-63.

[34] Premachandra BN, Ibrahim II. A simple and rapid thyroxin radioimmunoassay $\left(\mathrm{T}_{4}-\right.$ ria) in unextracted human, serum, composition of $\mathrm{T}_{4}$-ria and $\mathrm{T}_{4}$ displacement assay $\mathrm{T} 4$ (D) in normal and pathologic sera. Clin Chim Acta 1976; 70: 43-60.

[35] Chapra IJ, Ho RC, Lam R. An improved radioimmunoassay of triiodo thyronin in serum and its application to clinical and physiological studies. J Lab Clin Med 1972; 80: 729-739.

[36] Ellman GL, Courtney KD, Andres V, Feather-stone RM. A new and rapid colorimetric determination of acetyl cholinesterase activity. Biochem Pharmacol 1961; 7: 88-95.

[37] Babson AL, Read AP. Determination of total acid phosphatase in serum. Am J Clin Pathol 1959; 32: 89-91.

[38] Dito WRC. Lactate dehydrogenase: a brief review. In: Griffiths JC. (ed.) Clinical enzymology. New York: Masson Publishing; 1979, p. $1-8$.

[39] Trinder P. Determination of blood glucose using an oxidaseperoxidase system with a non-carcinogenic chromagen. J Clin Pathol 1969; 22: 158-161.

[40] SAS Institute. SAS/STAT user's guide. Cary and New York: SAS Institute Inc.; 2000.

[41] Waller RA, Duncan DB. A Bayes rule for the symmetric multiple comparisons problems. J Am Stat Assoc 1969; 64: 1484-1503.

[42] Seddik L, Bah TM, Aoues A, Brnderdour M, Silmani M. Dried leaf extract protects against lead-induced neurotoxicity in Wistar rats. Eur J Sci Res 2010; 42(1): 139-151.

[43] Hwang DF, Wang LC. Effect of taurine on toxicity of cadmium in rats. Toxicology 2001; 167: 173-180.

[44] WHO. IARC monographs on the evaluation of carcinogenic risk of chemical to humans. Lyon, France: International Agency for Research on Cancer; 1972, p. 80-86.

[45] Abdou ZA, Attia MH, Raafat MA. Protective effect of citric acid and thiol compounds against cadmium and lead toxicity in experimental animals. J Biol Chem Environ Sci 2007; 2(2): 481-497.

[46] Murrey RK, Granner DK, Rodwell VW. Harper's illustrated biochemistry. 27th ed. Boston, New York, Singapore: McGrow Hill Comp. Inc.; 2006.

[47] Noriega GO, Tomaro ML, del Battle AM. Bilirubin is highly effective in preventing in vivo delta-aminolevulinic acid-induced oxidative cell damage. Biochim Biophys Acta 2003; 1638(2): 173-178.

[48] Mc-Lntire MS, Angle CR. Air lead: relation to lead in blood of black school children deficient in glucose-6-phosphate dehydrogenase. Science 1972; 177: 520-522.

[49] Goel A, Dani V, Dhawan DK. Zink mediates normalization of hepatic drug metabolizing enzymes in chlorpyrifos-induced toxicity. Toxicol Lett 2007; 169(1): 26-33.

[50] Antinio MT, Corredor L, Leret ML. Study of the toxicity of several brain enzymes like markers of neurotoxicity induced by prenatal exposure to lead and/or cadmium. Toxicol Lett 2003; 143: 331-340.

[51] Yousif AS, Ahmed AA. Effects of cadmium (Cd) and lead (Pb) on the structure and function of thyroid gland. Afr J Environ Sci Technol 2009; 3(3): 78-85.

[52] Zhang FQ, Wang YS, Lou ZP, Dong JD. Effect of heavy metals stress on oxidative enzymes and lipid peroxidation in leaves of two mangrove plant seedlings (Kandelia candel and Bruguiera gymnorrhiza). Chemosphere 2007; 67: 44-50.

[53] Stohs SJ, Bagchi D, Hassoun E, Bagchi M. Oxidative mechanisms in toxicity of chromium and cadmium ions. J Environ Pathol Toxicol Oncol 2000; 19: 201-213.

[54] Reza B, Ali N, Mustafa M, Alireza A, Ali K. Cardiac responsiveness to beta-adrenergic in rats with lead-induced. Biol Med 2009; 1(4): 75-81.

[55] Mudipalli A. Lead hepatotoxicity and potential health effects. Indian J Med Res 2007; 126(6): 518-27.

[56] Adegbesan BO, Adenuga GA. Effect of lead exposure on liver lipid peroxidative and antioxidant defense systems of proteinundernourished rats. Biol Trace Elem Res 2007; 116(2): 219-225.

[57] Uzbekov MG, Bubnova NI, Kulikova GV. Effect of prenatal lead exposure on superoxide dismutase activity in the brain and liver of rat fetuses. Bull Exp Biol Med 2007; 144(6): 783-785. 